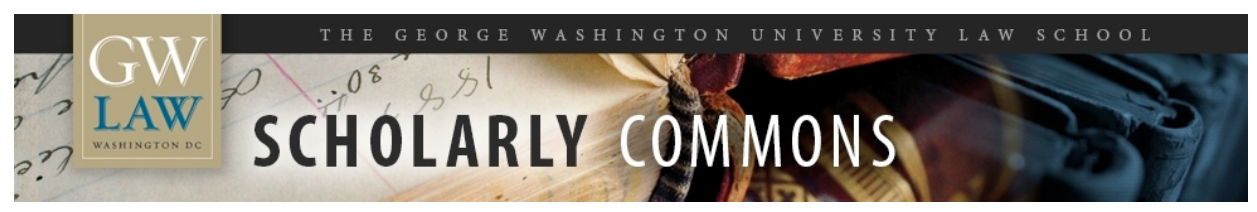

\title{
New Opportunities for Nongovernmental Actors in the International Law Commission
}

Steve Charnovitz

George Washington University Law School, scharnovitz@law.gwu.edu

Follow this and additional works at: https://scholarship.law.gwu.edu/faculty_publications

Part of the Law Commons

\section{Recommended Citation}

Charnovitz, Steve, "New Opportunities for Nongovernmental Actors in the International Law Commission" (2010). GW Law Faculty Publications \& Other Works. 402.

https://scholarship.law.gwu.edu/faculty_publications/402

This Article is brought to you for free and open access by the Faculty Scholarship at Scholarly Commons. It has been accepted for inclusion in GW Law Faculty Publications \& Other Works by an authorized administrator of Scholarly Commons. For more information, please contact spagel@law.gwu.edu. 


\title{
New Opportunities for Nongovernmental Actors in the International Law Commission
}

\author{
Steve Charnovitz*
}

Four years ago, I wrote an essay for the Centennial celebration of the American Journal of International Law on the topic of "Nongovernmental Organizations and International Law." In the section of that essay where I discussed whether, under international law, states and international organizations have a duty to consult nongovernmental organizations (NGOs), I surveyed some current practices of consultation in international organizations. Following a discussion of the current limited opportunities for civil society to engage in the deliberative processes of the World Trade Organization (WTO), I wrote:

Another (embarrassing) footdragger is the International Law Commission (ILC), which does not provide opportunities for NGO consultation. Yet it seems only a matter of time until a more progressive approach to codification flowers there, too. The ILC already has authority in its Statute to "consult with any international or national organizations, official or non-official, on any subject entrusted to it if it believes that such a procedure might aid it in the performance of its functions.” A good first step for the ILC would be to hold a one-day public hearing during its annual session.

My invitation to participate in this symposium has presented me an opportunity to revisit those thoughts, to conduct more research, and to update our scholarship on how the ILC processes use input from private actors.

When I wrote the essay in AJIL, I was unable, due to the strict page limitations, to include a vignette about the interface between the ILC and NGOs. During the $54^{\text {th }}$ Session (2002), the Summary Records state in part:

36. Mr. KOSKENNIEMI noted that during its current session the Commission had embarked upon the topic of the fragmentation of international law, a subject of great importance and complexity, and that a study group had been set up to consider its exact scope. ... Another, more substantive aspect had to do with the diversification of law-making, in other words, the emergence of informal ways of creating international law not only through regular diplomatic means 
or the classical subject of international law but through various types of normative practice undertaken by representatives of civil society. That seemed to be where the future of international law lay, and the topic of fragmentation sought to address that issue.

38. Inasmuch as the codification of international law by such bodies as the Commission was beginning to look like an archaic relic, it was increasingly necessary to involve representatives of civil society, such as international companies, non-governmental organizations and their networks. In autumn 2001, he had met with a number of United Nations bodies in Geneva and inquired what the Commission should do to help them in their activities in the field of refugee protection, human rights or international trade. Their reply: the Commission should not become involved! He urged the Legal Counsel to consider how the Office of Legal Affairs might cooperate with the Commission to devise programmes that reached out to civil society, which had not shown any interest in the Commission's codification work either. One way would be by assisting the Commission in its study on the fragmentation of international law.

This effort by Martti Koskenniemi to take note of the potential contribution of NGOs and to promote more inter-communication with them is notable. But the punch line of his remarks shows that efforts to promote greater cooperation between the ILC and NGOs on common projects can meet scepticism not only in the ILC, but also among the NGOs. Thus, the project to increase access to the ILC for NGOs will not be one that is driven by civic society because many social and economic actors do not, at present, perceive a strong need to try to influence the ILC.

My presentation this afternoon contains three parts: First, my paper will survey ILC practices and trends in consultations with NGOs, business groups, academics, and practitioners. Second, my paper will discuss why the ILC should consult NGOs. Third, my paper will offer concrete proposals for additional steps that the ILC should take to enhance its dialogue with private economic and social actors.

\section{A Survey of ILC Consultative Practices}

Doing research on NGO involvement in the ILC is not easy. The ILC website does not provide many details and I was not able to find any case studies on ILC-NGO collaboration. Below I have a brief summary of what I was able to find, but I do not think it is a comprehensive survey. 
NGOs have been consulted on several recent ILC projects. In the project on Protection of Persons in the Event of Disasters, the Commission considered written replies submitted by the International Federation of the Red Cross and Red Crescent Societies to the questions addressed to them by the Commission in 2008.

The role of civil society also formed a substantive part of the ILC's work on the protection of persons in disasters. The topic of civil society was considered in the second report of the Special Rapporteur. In the 2009 Session of the Commission, there was discussion of the comparison of the terms "civil society" versus NGO. Under this project, the proposed Draft Article 3 suggests that States have a duty to cooperate with the International Federation of the Red Cross and Red Crescent, and with civil society.

In the Project on the Obligation to Extradite or Prosecute, analysis by Amnesty International were discussed as early as the 2006 report of the Special Rapporteur. In February 2009, Amnesty International released a report about the ILC's project which was shared with members of the ILC Working Group. I have also heard that there have been many informal communications from Amnesty International to members of the ILC.

In the Project on Shared Natural Resources, there were some consultations with the International Association of Hydrogeologists but I could not find details on that.

The ILC website notes that there have been consultations with the International Law Association (ILA) on several projects, but no details are given.

I have heard that the Commission once invited discussion with an ILA study group on the topic of groundwater and that this session did not go well.

I also heard that there has been consultation with practitioners in ILC's work on diplomatic protection but could not find any documentation on the ILC website.

I could not find any episodes of corporate involvement with the ILC.

I could not find evidence of NGO consultation on two current projects: the Responsibility of International Organizations and the MFN Clause.

Although I could not find information about consultations on the Project on the Expulsion of Aliens, I would guess that NGOs have tried to submit some documentation. 


\section{Why the ILC Should Consult NGOs}

As I explained in my AJIL article, all international organizations should regularly allow input from NGOs. NGOs can provide information that might not otherwise come from governmental and intergovernmental officials. Although it may go too far to say that NGOs seek to promote the community's common interest while governments are inherently focused on special, nationalist interests, NGOs clearly do serve as a check on government power and insular ideas of bureaucrats and other NGOs.

Thus, the rationale for allowing NGO input into the ILC is the same as for any other international organization.

The question could be asked, however, as to whether international organizations specializing in legal process should be exempt from NGO input. I do not see any good arguments for such an exemption. Quite the contrary; international and transnational legal process needs to be open to input from actors at all levels and statuses. Although I support greater opportunities for NGO input into the International Court of Justice and other courts, the case is even stronger for the ILC because it has an explicit statutory role on the progressive development of law.

In considering the ongoing projects of the ILC, I believe a strong case can be made that NGOs have something useful to contribute to all of them. To take one example, there is a great deal of interest by NGOs interested on the MFN clause and how it affects trade and investment. Looking ahead to future potential ILC projects, there would be NGO interest on new topics such as Climate Change, the Atmospheric Environment, the general rules of international law, or others.

\section{How the ILC Should Improve Transparency and NGO Participation}

The ILC does not have to reinvent the wheel on transparency and NGO participation. It can take advantage of the lessons learned in other international organizations. The important first step is to come to an agreement that the ILC should become more open.

In my view, NGO input would be valuable at every stage of ILC work. This should start with the proposals for and vetting of proposals for new projects by the Working Group on the Long-Term Program. NGOs should be also be involved in the substantive legal analysis by the special rapporteurs and, when they exist, working groups. After the ILC acts, NGOs can be involved in the consideration of matters at the 
United Nations and in the implementation of ILC draft articles (or other outputs) at the domestic level. Of course, in calling for more NGO involvement, I am not suggesting that the autonomy and independence of ILC members or UN member governments should in any way be infringed.

As I understand it, current ILC practice recognizes that the special rapporteur can seek input from NGOs. Moreover, several rapporteurs have done so. But what is not clear to me is whether all rapporteurs routinely do this or would know how to do this if they wanted to.

One proposal I would like to make is that a manual be written for how a new special rapporteur should engage with civil society. This would be a document written specifically for the ILC and could highlight the best practices already used by ILC rapporteurs or used in other legal processes with applicability to the ILC.

Meaningful NGO participation must go hand in hand with transparency however. So it is also important that the ILC increase its transparency by improving its website. In doing research for this presentation, I found it very difficult to use the ILC website. Here are a few specific suggestions on how this can be improved:

1. Whenever a draft report is posted, the ILC should set up a Blog on that topic so that accredited NGOs, academics, practitioners, etc. can make public comments on it. There are many news to do this, but the underlying idea is that all major statements should be subject to a public notice and comment process.

2. Provide information on the ILC website specifically for NGOs and civil society. The World Trade Organization website is a good model for that in its specific links for NGOs, parliamentarians, teachers, journalists, students, etc.

3. The website could post a document giving an institutional history how NGOs have contributed in the past in the ILC. Such a document could serve an educational purpose for NGOs and new ILC members.

In addition to the website improvements and the blog, I think the Commission should also do what I proposed in AJIL, which is that each year during its session in Geneva, the Commission hold a public hearing in Plenary to consider comments on any aspect of the ILC's work including the need for revision. Such a public hearing would be "cutting edge." Indeed, that is another reason why I would favor it for the ILC because its public participatory opportunities should be better than average in the UN, not, as they are now, lower than average. There could be a time set aside for ILC members to be asked questions by NGOs. 
At the moment that a new project is completed, I would like to see the ILC hold a public symposium to announce the draft articles or whatever the new output is. In addition to speakers from the Commission, one could also imagine commentators from governments, civic society, and governments. At such a symposium, there could be breakout sessions with ILC members and stakeholders to discuss how to disseminate information about the results from a new project. In other words, the ILC should recognize that its target audience is much broader than just the U.N. General Assembly and member governments.

Finally, let me address the role of the Secretariat. I have heard it suggested one way to facilitate greater NGO input into the ILC would be to have it filtered through the Secretariat. I do not know enough about ILC processes to comment on that suggestion. It may be that the usual more direct approach of NGOs to governments and international organizations is not optimal for input to an expert body like the ILC. On the other hand, it may be that NGOs should speak for themselves just as they do in other U.N. bodies, rather than have their views intermediated by international bureaucrats.

\section{Conclusion}

In my presentation to this Conference, I have tried to make the case for why the ILC should be more open to engagement with NGOs, and how this could make the ILC and its work more successful. I recognize that there could well be a concern that more public attention to the ILC and participation by stakeholders could distract the ILC from its duties or politicize its work. To be sure, enhancing the ILC's public interface needs to be done skillfully. But I am convinced that if it is done right, greater NGO involvement can strengthen the unique outputs of the ILC and make them more useful and relevant to governments and the public. Moving ahead now would be a good ILC initiative for the second decade of the 21st century.

*Steve Charnovitz is Associate Professor of Law at George Washington University. All rights reserved. 